\title{
Choosing Reviewers: Predictors of Undergraduate Manuscript Evaluations - CORRIGENDUM
}

\section{Christina P. Walker}

Terri L. Towner

\section{Lea Hilliker}

DOI: https://doi.org/10.1017/S1049096521001888. Published by Cambridge University Press, 8 February 2022.

Walker et al. 2022 contains an error in the Results section. In the third paragraph under "Results," the third sentence should read as follows: "Regarding race, the results show that white reviewers gave significantly higher originality ratings than nonwhite reviewers, with a reviewer's race being the most robust indicator."

The authors apologize for this error. -

\section{REFERENCE}

Walker, Christina P., Terri L. Towner, and Lea Hilliker. “Choosing Reviewers: Predictors of Undergraduate Manuscript Evaluations.” PS: Political Science E Politics. Published online 8 February 2022. https://doi.org/10.1017/S1049096521001888. 